\title{
Decentralization and local institutional arrangements for wetland management in Ethiopia and Sierra Leone
}

\author{
Roy Maconachie ${ }^{\mathrm{a}, *}$, Alan B. Dixon ${ }^{\mathrm{b}, 1}$, Adrian Wood ${ }^{\mathrm{c}, 2}$ \\ ${ }^{a}$ Institute for Development Policy and Management (IDPM), University of Manchester, Oxford Road, Manchester M13 9PL, UK \\ ${ }^{\mathrm{b}}$ Department of Applied Sciences, Geography and Archaeology, University of Worcester, Henwick Grove, Worcester WR2 6AJ, UK \\ ${ }^{\mathrm{c}}$ Centre for Wetlands, Environment and Livelihoods, University of Huddersfield, Queensgate, Huddersfield HD1 3DH, UK
}

\section{Keywords:}

Decentralization

Institutions

Wetlands

Wetland management

Ethiopia

Sierra Leone

\begin{abstract}
A B S T R A C T
In Ethiopia and Sierra Leone, recent social, political and environmental transformations have precipitated the intensification of wetland use, as local people have sought to safeguard and strengthen their livelihoods. Concurrent decentralization policies in both countries have also seen the government strengthen its position at the local level. Drawing upon recent field-based evidence from Ethiopia and Sierra Leone, this paper examines the compatibility between community-based local institutions for wetland use, and the process of decentralization. It argues that decentralization has in fact restricted the development of mature local institutional arrangements, due to its intrinsically political interventionist nature.
\end{abstract}

Crown Copyright $\odot 2008$ Published by Elsevier Ltd. All rights reserved.

\section{Introduction}

Wetlands are increasingly being recognized as vital resources for achieving food, water and livelihood security in many parts of sub-Saharan Africa (Dugan, 1990; Hollis, 1990; MEA, 2005; Roggeri, 1998; Silvius, Oneka, \& Verhagen, 2000; Stuip, Baker, \& Oosterberg, 2002). Traditionally, they have been used for a wide range of livelihood activities including fishing, agriculture and the collection of water, food and forage (Acreman \& Hollis, 1996; Adams, 1993; Dixon, 2003; Kangalawe \& Liwenga, 2005; Nicholas, 1998; Richards, 1995; Scoones, 1992). However, as profound social, political and environmental transformations across Africa have placed pressure on local livelihoods, in many cases poor households have sought to safeguard their livelihoods through the intensification of wetland use, especially in small wetlands which can be easily managed at the community level (Dixon \& Wood, 2003; Gichuki, 1992; Schuyt, 2005). With their rich, seasonally inundated soils, wetlands have become 'new agricultural frontiers' that provide important farming resources for a wide range of actors.

Despite the global recognition of the importance of wetlands as key livelihood resources, there have been conflicting approaches by African states to these areas, who predominantly either see them as areas to protect for environmental reasons or to use for commercial agro-development. State preferences for such single land-use, characterized by intensive cultivation or conservation sites, are often directly at odds with local preferences for mixed, multiple-use wetland regimes which can meet a variety of local needs and are potentially more sustainable. Although government policies on wetlands frequently embrace the rhetoric of 'multi-stakeholder participation' in wetland management for local, national and international sustainable development agendas, rarely has the debate involved any serious discussion of local community needs or the

\footnotetext{
* Corresponding author. Tel.: +44161306 6435.

E-mail addresses: roy.maconachie@manchester.ac.uk (R. Maconachie), a.dixon@worc.ac.uk (A.B. Dixon), a.p.wood@hud.ac.uk (A. Wood).

1 Tel: $+44(0) 1905542157$.

2 Tel: $+44(0) 1484473010$.
} 
institutional arrangements developed by communities to achieve these goals. Yet throughout the developing world, local people have a long association with wetlands, and as a result, local institutions and institutional practices have developed which have sought to sustain the multiple benefits from wetlands. Local institutions are usually rooted in community social capital, rather than external, top-down decision-making processes, hence they are dynamic, flexible and responsive to societal and environmental change, and have been regarded as important 'buffering' mechanisms that promote sustainability and resilience at the environment-society interface (Mazzucato \& Niemeijer, 2002). A critical area of debate, however, centres on the development and sustainability of local institutions themselves; whether they can continue to function and support sustainable natural resource management (NRM) strategies in the context of rapid change, or increased intervention from external state institutions (Agrawal, 2001; Manig, 1999; Rasmussen \& Meinzen-Dick, 1995). The current wave of decentralization sweeping across sub-Saharan Africa, characterized by increasing state interaction with local communities, has profound implications for the effectiveness of local community institutional arrangements. Although various policies framed under the guise of 'community-based natural resource management' and more recently, the 'devolution of resource rights to local communities', have been heralded as the way forward in sustainable wetland management, recent studies suggest that the social and economic benefits of decentralized natural resource management initiatives do not always accrue to local actors (Fabricius, Koch, Turner, \& Magome, 2004; Ribot, 2004).

Drawing upon recent field-based evidence of wetland management in Ethiopia and Sierra Leone, this paper examines this relationship between decentralization in natural resource management policy, and the effectiveness of local community institutional arrangements. In effect, it seeks to address the question of whether both can co-exist, and facilitate the sustainable management of wetlands and their associated livelihood benefits.

\section{Conceptualizing institutions in a wetland context}

A burgeoning body of work by social scientists has focused on the notion of 'institutions' as a social practice in relation to natural resource management (Berry, 1989; Leach, Mearns, \& Scoones, 1999; Mazzucato \& Niemeijer, 2002; Mehta et al., 1999; Uphoff, 1992). Although the term 'institutions' can refer to the organizations involved in natural resource management, in this context the concept is employed in a wider sociological sense to refer to 'regularised patterns of behaviour between individuals and groups in society' (Leach, Mearns, \& Scoones, 1997: 5), and also links to other groups and individuals at higher and lower levels. In this broader sense, institutions include the formal and informal mechanisms that play a defining role in shaping the access that a group has to natural resources, and may also determine who has the rights to resources within that group (Watson, 2001). However, other observers have also pointed out that it can be problematic to conceive of institutions merely as rules themselves, since the distinction between rules and social practices can at times become blurred (Leach et al., 1997). For example, Watson, Black, and Harrison (1999) note that recent academic work on 'every day' forms of resistance highlights how behaviour that deviates from a prescribed code of rules can itself become institutionalized. Since different social actors command varying degrees of organizational capacity when it comes to resource use, the informal rules and regulations associated with institutions are ultimately about power. In this light, Davies (1997: 24) notes, 'institutions are the social cement which link stakeholders to access to capital of different kinds to the means of exercising power and so define the gateways through which they pass on the route to positive or negative [livelihood] adaptation.'

Closely related to the process of institutional analysis, the concept of social capital, comprising the informal values, networks, knowledge and rules inherent in a particular society, has been widely explored in rural development research (for example, see Narayan \& Pritchett, 1999; Pretty \& Ward, 2001). While social capital may include the processes of communication and innovation that are necessary for new wetland knowledge and practice to evolve (Dixon, 2005), it also constitutes the 'space' in which 'traditional' wetland institutions exist (Dixon \& Wood, 2007; Shivakumar, 2003). Although the concept has been extensively critiqued (Fine, 2001; Harriss \& de Renzio, 1997), the significance of social capital, as a precursor to the development of institutional arrangements, remains important in understanding how the interconnectedness of people and networks of trust and norms may help societies cope in uncertain times. In societies that have been affected by conflict, there are often complex challenges in rebuilding social capital, which remains vital in operationalizing collective action and mobilizing community-driven development (Richards, Bah, \& Vincent, 2004).

Of critical significance for wetland management is the way in which the social capital and relationships of reciprocity that exist between farmers are reshaped by more powerful actors, and affect the character and strength of community-based institutions. Such institutions, either formal or informal, are based upon a set of rules or procedures that have often developed progressively over time and have been affirmed by community leaders and members (Blunt \& Warren, 1996; Shivakumar, 2003). The co-ordination of activities within a community remains critically important to the management of wetland resources, where one farmer's actions directly affect another's. In this respect, the formation or existence of institutions that governs management behaviour is particularly vital, and reflects the need for co-ordination of activity in working towards a particular goal, which could probably not be fully achieved by individuals alone. Wetland agriculture, especially where drainage structures and water management are involved, is a prime example of a natural resource management activity requiring such co-ordinated effort.

Customary multiple-use wetland regimes are based on experience built up over generations by local communities. Wetland management, particularly resource access and control, is shaped by the intersection of various institutions and the relationships of power and authority that exist between them. For example, in the Eastern Province of Sierra Leone an informal code of conduct to guide management practices exists among wetland managers at the micro-level, but these rules 
are frequently influenced by institutional practices at wider scales. For example, the 'customary' laws of the Native Administration, local government policies concerning land management, agricultural policies of the line ministries, and the conditionalities of international donor agencies all play a role in shaping - either directly or indirectly - approaches to community-based wetland management. Moreover, the broader backdrop of a post-conflict environment, and all the institutions associated with post-war reconstruction, further play a role in re-casting people-environment relationships at the micro-level. In Ethiopia, local institutions have developed both in recent decades in response to land reform and increased access to wetlands, as well as in previous times before the 20th century under traditional institutional arrangements governing local natural resources. These institutions have developed rules concerning 'best management practices' in wetlands, to ensure that drainage is coordinated and wetland use is managed in a way which prevents serious environmental damage. However, these can also be upset by local or external influences, including the state. In short, in both Ethiopia and Sierra Leone, understanding institutional processes and appreciating how patterns of resource use may be outcomes of negotiation between various social actors with different priorities, remain at the heart of exploring the politics of resource use in wetland environments.

\section{Decentralization and community institutions: a new space for interaction between state agencies and communities?}

In recent years, the growing trend towards decentralization in sub-Saharan Africa has been strongly advocated as one way of addressing the social inequality and uneven power relations that have become prevalent on many parts of the continent. In response to structural adjustment policies and the increasing importance of accountability, democracy and local participation, the emergence of decentralization initiatives has rejuvenated governance and development debates, raising important questions that concern the role of local government in poverty eradication (de Oliveira, 2002). Decentralization is often motivated by the idea of bringing government closer to the people, a move that many observers maintain will allegedly create new spaces for increased interaction between state agencies, traditional leaders and communities. Indeed, in recent years, there have been growing calls for greater public participation in decision-making processes throughout the developing world, with more attention being given to issues of democratization, accountability and transparency (de Oliveira, 2002).

Although the experiences with decentralization in Ethiopia and Sierra Leone are quite different, the current emphasis in development policy in both countries is to decentralize the state's management and responsibilities, in order to improve the degree of contact with local communities and beneficiaries. In Ethiopia, regionalism has been a major issue for much of its recorded history, which goes back for many centuries. Recent experience of this has been seen in the prolonged struggle for independence by Eritrea and by the sporadic insurgency in the Oromo and Somali parts of the country. The Derg government, which removed Haile Selassie from power in 1974, began to address this issue towards the end of the 1980s through a new internal administrative structure which gave some of the newly created administrative areas a form of autonomy. This was replaced after the present government came to power in 1991 with a predominantly ethnically-based administrative structure with eight ethnic regions and three urban administrative regions. In the early part of the present decade, the government introduced further reforms to the internal administrative structure of these regions, removing the intermediate zonal level and requiring the district to be the only sub-regional administrative tier. This was specifically termed decentralization, and although this was in part an attempt to get more technical staff at the district level, it was also an attempt to develop the political process at this level and improve control over these areas (Hamer, 2007).

At the community level in Ethiopia, there have also been progressive changes over the last thirty years. Initially tied to the land reform of 1975, Peasant Associations (PAs) were set up to organize farmers after the removal of landlords in the south and traditional clan-based elites in the north. The PAs were responsible for the allocation of land, and its regular reallocation to maintain equity in terms of land holdings. They also administered both farm and non-farm land with some concerns for sound management and sustainable use (Wood, 1983). In the last ten years, the PAs have been re-arranged, with many being merged together to create larger kebeles, which are the new community administrative units. These have one person paid by the state, and the duties of that chairperson and the committee are now primarily politico-administrative, rather than concerned with land redistribution which has been halted. At the PA/kebele level, the state has sought to provide agricultural support through the posting of development agents (DA). Initially, it was a struggle to get one DA per PA under the Derg, but the goal recently announced by the present government is to have three DAs per kebele, with each having different responsibilities - one for crop production, one for livestock and one for natural resources.

On the other hand, the specific model of decentralization adopted in Sierra Leone is premised on the notion that traditional leaders will continue to work alongside elected councillors, with chiefs being responsible for rural security, justice and land issues, and local government being liable for rural 'development' and service delivery. In such instances, Toulmin (2000: 244) warns that there is a risk of tensions developing between the two systems of authority, if the division of responsibilities is not clear. While it would appear that the decentralization of responsibilities for agriculture, and natural resources more broadly, should provide great opportunities for increasing the relevance of local authorities to local people, at the same time, "power sharing' remains a threat to central authorities, traditional leaders and elites, who may in fact fear a loss of power, income or patronage resources. Other observers have pointed to the considerable political conflict and resistance that have ensued in similar scenarios elsewhere in sub-Saharan Africa, where power and resources have been redistributed under the banner of decentralization initiatives (Ntsebeza, 2004).

Efforts to transfer legal and political authority from central government to subordinate units of government are not new in Sierra Leone. In 1808, during the colonial years, Freetown was initially established as a Crown Colony. Later in 1896, the 
interior of the country was declared a British protectorate where five administrative districts were created, each of which was governed by a British District Commissioner. Under this system, Sierra Leone developed as a 'bifurcated state' where a Crown Colony was administered directly under 'European' laws, and at the same time, District Commissioners ruled a larger protectorate indirectly through 'traditional authorities' (see Mamdani, 1996). These two administrative units existed in complete isolation from each other until a new constitution was drafted in 1951. Following independence in 1961, a form of decentralized government developed under the Margai government (1961-1964), but with increasing centralization of power and resources under the APC regime, local government and the district councils were eventually abolished in 1972.

During the 1980s, Sierra Leone was characterized by an 'over-centralization' of power under Siaka Stevens' APC government, which many observers believe was responsible for fomenting the pre-conditions for the decade-long civil war during the 1990s. The causes of the debilitating conflict were complex, and an extended discussion of events leading up to the war is beyond the scope of this paper. However, it is commonly agreed that the origins of instability extend back well beyond the last 15 years, and embody a mixture of factors including bad governance, the denial of fundamental rights, economic mismanagement and social exclusion (UN, 2004). While an understanding of the factors leading to war remains important, much has been written on this elsewhere (see for example, Adebajo, 2002; Noyes, 2003; Richards, 1996).

Larson and Ribot (2004) point out that although governments may decide to devolve power for a variety of political, economic, social and ideological reasons, it is often the intense pressure from donors and aid agencies that is the driving force behind decentralization initiatives. In Sierra Leone, where it is estimated that donors currently provide some 50 per cent of Government revenue, external agencies have placed strong emphasis on decentralization as a 'political conditionality' for post-war reconstruction assistance (Jackson, 2005: 50). Such reform programmes are frequently driven by globalized conceptions of 'effective markets' and 'good governance' and have significant impacts on localized processes that shape people's livelihoods (Mehta et al., 1999).

Many initiatives to decentralize structures of government invariably interact with local interests and relationships of power in complicated ways. Ultimately, this interplay can serve to reinforce or enhance different patterns of privilege, creating new forms of exclusion that are often couched in well-meaning platitudes claiming to protect community rights (Berry, 2004). A number of recent studies suggest that many of the assumptions that concern decentralization need to be carefully assessed, as conflict over natural resources and contested institutional responsibilities between competing usergroups have become increasingly common (Crook, 2003; Ribot, 2004). In the case of Sierra Leone, observers have warned that in its present form, there is a risk that decentralization may become old wine in new bottles, as the 'old way' of doing politics threatens to re-surface in a new guise (Fanthorpe, 2006; Hanlon, 2005; Jackson, 2007). In the Ethiopian scenario, at present there are concerns that some local institutional arrangements are breaking down due to a lack of support from local administrative structures, despite the process of decentralization, and this has major implications for the sustainable use of wetland resources and food security throughout the region.

\section{The case study experiences: Ethiopia and Sierra Leone}

Ethiopia

With the exception of the rift valley lakes and Lake Tana, the source of the Blue Nile, Ethiopia's wetlands remain under recognized and undervalued resources (Abebe \& Geheb, 2003). Seasonally and permanently flooded swamps, marshlands and floodplains are, however, ubiquitous throughout the central highland plateau, and extensive in some lowland areas such as Gambella. In the administrative zones of Western Wellega and Illubabor (Fig. 1) permanent and seasonal swamp-like wetlands occupy approximately 4 per cent of the region's land area. In addition to fulfilling a range of environmental regulating services, these wetlands provide numerous socio-economic benefits for local people; they are a source of clean drinking water, craft and construction materials, and medicinal plants. They also provide dry season grazing areas for cattle, and critically, they are an important agricultural resource; maize, vegetables and cereals are cultivated on the residual moisture during the dry season (October-May) by those who have access to wetland plots (Solomon, 2004).

Wetland cultivation in south-west Ethiopia dates back to the mid-19th century (McCann, 1995) and may go back many centuries earlier according to recent coring results (Wood, Rushworth, \& Corr, 2005). More intensive forms of wetland cultivation were, however, initiated in response to food shortages in the early years of the 20th century, when feudal landlords during the Haile Selassie era (1930-1974) either instructed their peasant farmers, or granted a request from them, to cultivate wetlands to increase food production. The agricultural utilization of wetlands increased further during the Derg period (1974-1991), when land was nationalized, regional targets for food self-sufficiency were set, and the expansion of coffee production reduced the availability of upslope agricultural land. Since the change in government in 1991, pressure to intensify wetland cultivation throughout the area has increased and in 1999, a Wetlands Task Force was established in each kebele to oversee the more intensive cultivation of wetlands. Ironically, while the implementation of this policy may have an impact on food security in the short term, it represents a major threat to the sustainability of wetland agriculture, since it threatens to override locally adapted management practices, and the community-based local institutional arrangements governing wetland use.

A research programme investigating the significance of local institutions for wetland management was undertaken in Western Wellega (four sites) and Illubabor (four sites) between January and December 2003. Local farmers were invited to participate in a programme of participatory rural appraisal (PRA), employing activities such as ranking, proportional piling 


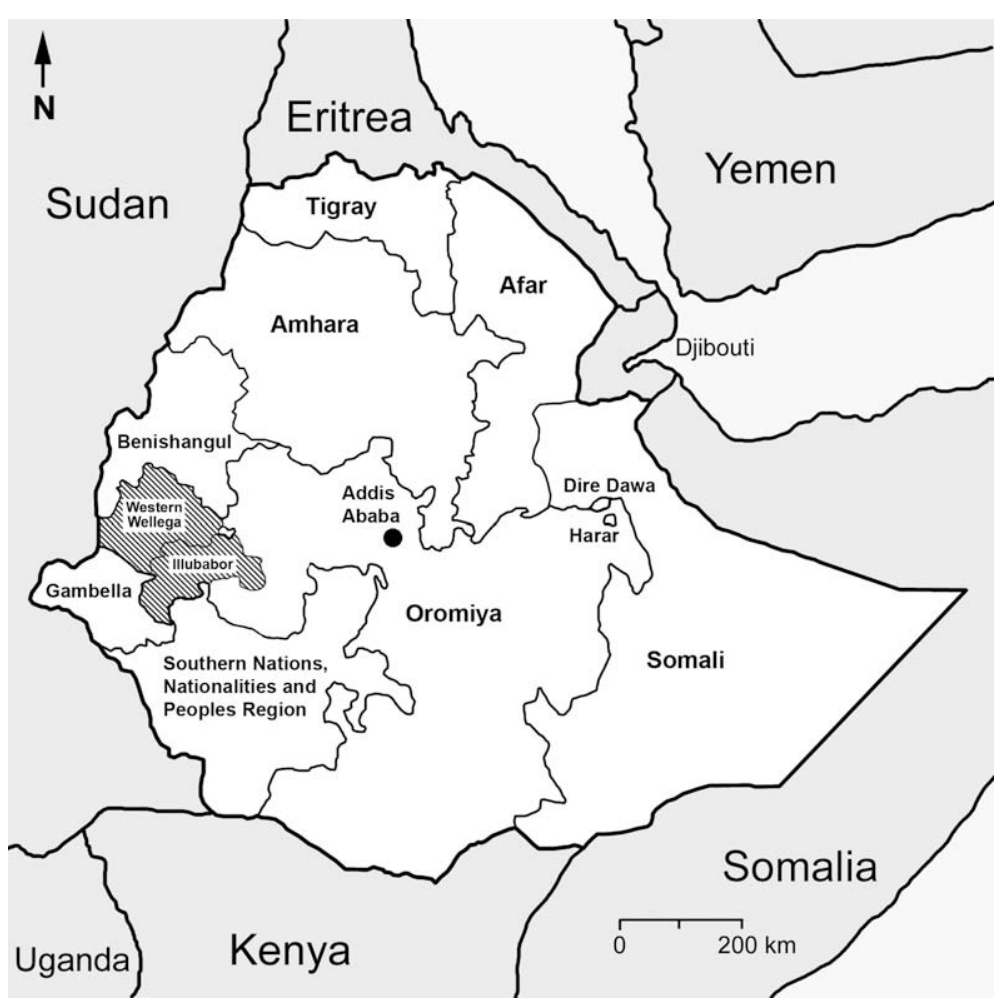

Fig. 1. Western Wellega and Illubabor.

and venn diagramming (see Chambers, 1997; Grenier, 1998). The perceived functions of local institutions were ranked by participants in order of their importance for wetland-based livelihoods, then proportional piling was used to measure the relative magnitude of importance between each function. Venn diagrams were constructed specifically to indicate the relationships between local wetland management institutions and other community and external institutions and organizations. Each PRA session typically lasted between 1 and $2 \mathrm{~h}$, with an average of nine wetland farmers participating in each session per site (a total of 111 farmers participated in the study). Follow-up interviews were held with key informants within the communities as well as local government and NGO staff.

The results suggested that local institutional arrangements for managing wetlands are common throughout Illubabor and Western Wellega. Typically, the institutions comprise agreements (often formalized in a written constitution) between farmers cultivating in each wetland, on issues such as appropriate drainage practices, reciprocal co-operation in drainage, cultivation and guarding, and measures for conflict resolution. With the latter, the institutions retain the right to fine or punish those who fail to comply with the various agreements. The resulting informal farmer associations are, therefore, bonded by concerns for effective and sustainable wetland use. Indeed, a critical function is their role in controlling potentially destructive agricultural practices, such as excessive cattle grazing, which leads to the compaction and erosion of soil in wetlands. In some areas, the institutions restrict wetland cultivation to only one crop per year, whilst also prohibiting the cultivation of tef, sugarcane, or the increasingly ubiquitous eucalyptus that are damaging in terms of their soil and moisture requirements. There is evidence that prior to the influence of the kebele wetlands task force, it was local wetland associations that were bound by institutional arrangements, that decided whether whole wetlands should be used for cultivation, reserved for cheffe (sedge) production, or left to regenerate if the wetland was perceived as being degraded.

The institutional organizations themselves are known by a variety of names, which to some extent reflect the history of wetland cultivation. In both Western Wellega and Illubabor, institutions are known as Abba Laga (father of the water) or Abba Adere (father of the villagers) (Dixon \& Wood, 2007). According to farmers, these are modifications of traditional sociocultural institutions that formed part of the Oromo Gada system of administration in the late 19th Century (see Desalegn, Singh, Das Gupta, \& Seleshi, 2007). However, despite the implied continuum with traditional indigenous institutions of the past, the research revealed that in Illubabor in particular, where wetland cultivation post-dates that of Western Wellega, most institutions were developed relatively recently; in many cases through the intervention of state institutions.

During the Haile Selassie era, it was common practice for either the landlord to appoint an Abba Laga leader to instigate institutional arrangements for wetland cultivation, or for farmers themselves to propose an Abba Laga. Land nationalization during the Derg era brought about the redistribution of wetland plots, and in the absence of landlords, placed wetland management arrangements firmly in the hands of the wetland users themselves. The newly formed PAs, however, were 
assigned ultimate responsibility for overseeing the functioning of the institutions, and in the opinion of most farmers, the PAwetland institution relationships formed during this era were the most productive in terms of efficient and successful wetland management. Conflict between farmers over issues such as the timing of drainage, or participation in pest guarding, was a rare occurrence on account of the strong punishments imposed by a supportive PA. Although like the feudal landlord, it often intervened directly in wetland use issues in a top-down manner, it arguably provided a means of backstopping and legitimizing the wetland management institution.

Since the overthrow of the Derg in 1991, the federal government's focus on regionalization and decentralization appears to have had both positive and negative impacts. Most wetland management institutions have undergone self-induced change to fit in with the newly devolved democracy promoted by the government, for example by increasing membership of the wetland management committee, i.e. those farmers who oversee the functioning of the institution, to make it more transparent and accountable to its members. Many farmers, however, protest that the concept of democracy has been misinterpreted by wetland users who wish to 'exercise their individual democratic right' not to participate in institutionally managed activities such as ditch digging or guarding against wild pests. The local institutions, and arguably social capital among wetland cultivators, have also been eroded further, some farmers say, by the lack of interest shown by the kebele administration in addressing such problems, and in wetland management generally. The reasons offered by farmers for this lack of kebele support vary from corruption among the kebele committee, to a simple lack of available time and resources, in the light of more pressing socio-economic and political concerns. The paradox, however, is that despite a process of decentralization that could potentially empower new opportunities for state-local institution collaboration and strengthening, most wetland management institutions now exist in a more weakened state than ever before since their mechanisms of enforcement have been removed.

The politics of decentralization, in terms of emphasising the legitimacy of government, rather than community institutions, and the threat which is sometimes perceived by government to come from such local institutions, is possibly behind some of the loss of respect for the institutions among their membership, and the lack of support provided by the kebele administration. Both, according to farmers, have weakened their capacity to coordinate wetland management and enforce what are ultimately reciprocally beneficial rules and regulations that influence wetland sustainability. The solution, according to farmers, is greater external intervention in wetland management institutions; they regard the kebele administration as essential for legitimizing and backstopping the rules and decision-making processes that are at the core of local wetland management arrangements. Many would like to see the kebele encouraging more farmers to sign written constitutions for wetland management, which include enforceable penalties for non-compliance. Yet clearly in this way, decentralization may be leading to the incorporation of the wetland management institutions into the government system. Close links to the kebele, as a government-biased institution, could well encourage the use of wetlands in an unsustainable manner, in pursuit of politically important policies such as short-term regional food security, as has already occurred via the influence of the Wetlands Task Force. With local government intervening more in the day-to-day operations of wetland management, a key concern is whether this would erode further what social capital remains among these institutions, hence their adaptiveness, flexibility and capacity to operate effectively outside the vagaries of bureaucratic government administrations.

\section{Sierra Leone}

The inland valley swamps, which occupy an estimated 600,000 ha and are widely scattered throughout the country, have long been recognized as important wetland resources for ensuring food security, through the production of rice, vegetables and other commodities. Today, in the post-conflict scenario, the strengthening of local institutions involved in wetland management could play a vital role in the improvement of rural livelihoods, and there is a sense of urgency amongst government policy makers and various other bodies, to increase the productivity of the inland valley swamps to ensure food security and alleviate poverty. Since 2001, it is estimated that more than 543,000 displaced persons have returned to their mainly rural home areas to begin the process of rebuilding their livelihoods which are heavily dependent on agriculture (UN, 2004). In his inauguration speech in July 2002, former President Kabbah vowed that his government would focus on achieving food security and agricultural sustainability, within a decentralized system which would rebuild institutions and improve governance (Kabbah, 2002). As part of this initiative to ensure future national food security, the Ministry of Agriculture has recently stressed the potential for the development of enhanced wetland rice production in the inland valley swamps as a key government policy (Government of Sierra Leone, 2004).

Between May and June 2004, June and September 2005, and November and December 2006, field-based research was undertaken in two rural communities in the Eastern Province of the country - Kayima (Kono District) and Panguma (Kenema District). Both of these communities suffered badly during the war, and both are currently in the process of rebuilding wetland management institutions and regimes (see Fig. 2).

At both sites, primary data were collected at the community and lower government levels through a programme of participatory sessions held on site in wetland areas. For example, farmers produced seasonal calendars to highlight changes in specific wetland activities over the course of the year, and the construction of time lines was useful for exploring how changes in farmer-wetland interactions had taken place over time. Participant observation also played a key role in the research and close contact was maintained with community wetland groups at both study sites over the course of the fieldwork period. Crucial insight into the institutional challenges faced by local actors was gained by working with labour groups during the preparation of their wetland farms, as well as attending community and wetland group meetings. Focus group discussions 


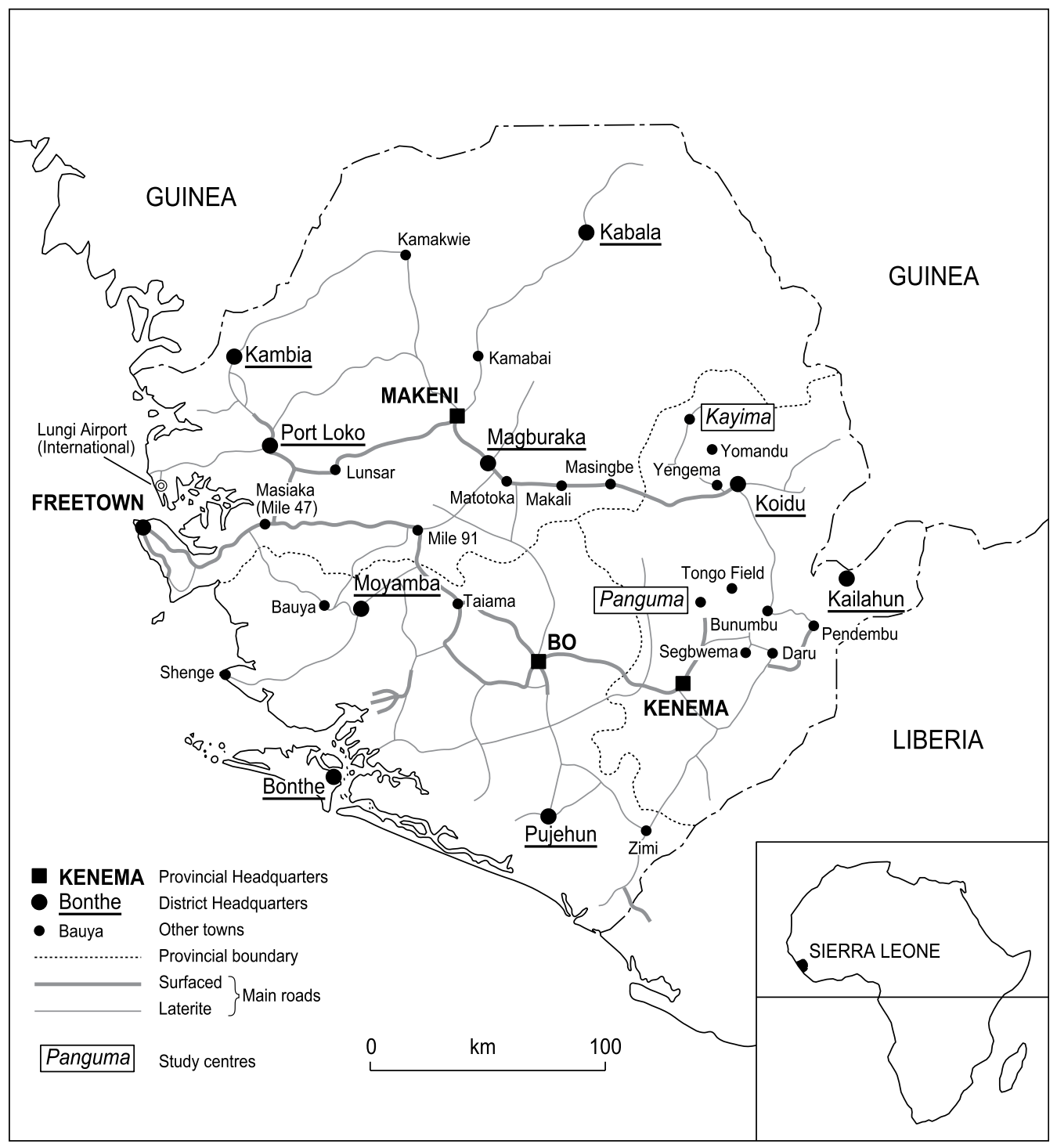

Fig. 2. Study sites in Sierra Leone.

and interviews were also conducted with key informants, which included a wide range of various wetland management stakeholders. Interviews with 100 households involved in wetland agriculture were conducted in Kayima and Panguma between May and June 2004. Further interviews were carried out with the paramount chiefs at each site, as well as a number of district councillors, and NGO and government staff in the towns of Koidu (near Kayima) and Kenema (near Panguma).

While many individuals interviewed believed that in the post-conflict period, the strengthening of local wetland management institutions could play a vital role in improving rural livelihoods, the research also revealed that there are a number of institutional challenges that first must be addressed. Many of these challenges were similarly found in Ethiopia. For example, wetland agriculture in Sierra Leone is characterized by a distinctly peaked seasonal labour profile. Traditionally, large reciprocal work gangs of 'company' labour (referred to as boma groups in Kono and kombi groups in Mende) have been vital in co-ordinating a number of crucial farm operations which must take place over a relatively brief growing period. As is certainly the case with the coordination of drainage and clearance activities in Ethiopia, fieldwork in Sierra Leone revealed that even individuals who presently find themselves with formal access to sufficient swampland can still find themselves to be 'land poor', because they do not have access to what Mamdani (1996) refers to as the 'implements' of production (i.e. the 'food for work' or social capital) necessary to set the labour cycle in motion. It would appear that considerable benefits accrue to the farmer with the networks, social skills and opportunities to organize large working parties, and as Adger (2000) points out, strong social capital that promotes adaptation and social resilience, is an important pre-requisite to environmentally and socially sustainable natural resource management. In the pre-war period in the Eastern Province, it may have been the case 
that those families with more material wealth at their disposal were better able to form patron-client relationships and consequently may have also possessed stronger social capital and the networks required to access labour. In the post-conflict scenario, however, it is apparent that relationships of trust and reciprocity between different social actors have been greatly challenged. As one farmer put it, 'the war has made us all poor now'.

The institutional challenges associated with gaining access to wetland labour, and indeed farm labour more broadly, are well recognized in Sierra Leone. In addition to the constraints associated with organizing reciprocal labour groups, discussions with grassroots actors revealed that within the agricultural sector, most of the formal farmers' associations and community-based groups that were thriving before the war were no longer functioning. In recognition of this institutional vacuum, the government has recently acknowledged that support to agricultural associations, rather than just to individual farmers, together with provision of agricultural training in rural communities, should be major priorities for development (Government of Sierra Leone, 2003). At the forefront of efforts to decentralize the Ministry of Agriculture and support democratic grassroots institutions, the 'Agricultural Business Unit' (ABU) initiative has recently been introduced, a joint venture between the government and the UNDP. By mobilizing farmers into community-based associations and encouraging members to combine their resources, there is great hope that ABU farmer groups will be able to effectively deal with the labour issue. Labour cooperation in the groups is typically modelled on traditional reciprocal arrangements, such as boma or kombi groups, and many of the ABU associations are currently involved in wetland cultivation.

In addition to pooling their labour efforts, ABU farmers are also encouraged to increase the overall acreage they are cultivating, save a certain percentage of their personal harvest for 'development', pay a 'community contribution' to the local council, and monitor the activities of local government to ensure that resources are being invested in services that are meaningful and relevant to local people. One of the major objectives of the programme is to stimulate increased revenue mobilization for the local councils themselves, and it is anticipated that eventually, ABU farmer contributions could account for as much as one third of the total local council budget (Tom Cairnes, UNDP, pers. com., 28 June, 2005). During the initial years of the programme, the Ministry of Agriculture has vowed to provide ABU farmers with training, rice seed loans, and eventually access to micro-credit, confirming the government's commitment to a 'package approach' to agricultural recovery.

Overall participation in the ABU scheme is significant - each group is composed of 400 farmers, and as of June 2005, there were 140,000 participating farmers, and 347 ABU groups nationwide (UNDP, 2006). Kono District reported having 38 ABU groups, while Kenema District confirmed having 32 groups. During the course of fieldwork, research contact was limited to three different ABU groups that were engaging in swamp agriculture in the Eastern Province. Discussions with members in both Kayima and Panguma revealed that although the ABU scheme was generally perceived to be a much-needed attempt to re-establish grassroots associations and facilitate livelihood recovery, there were a number of important concerns that had emerged in the early stages of their development - particularly concerns to do with accountability and the lack of meaningful engagement between farmers and the local council. These grievances had caused some farmers to become sceptical of the overall mandate of the initiative, and had led several individuals to question whether the government actually had a hidden transcript underlying the formation of the groups. High levels of mistrust were reported between farmers, local agricultural staff working under the Ministry of Agriculture, and local councillors, and allegations of power abuse, misuse of funds and corruption were noted during interviews.

In short, in order for the ABU programme to function effectively, it is essential that there is frequent and meaningful engagement between the farmers and the local council. Indeed, a lack of contact between the two groups was one of the main criticisms of the initiative, from both ABU members and local councillors themselves. While farmers reported that councillors were not interested in coming to the swamp to learn about their problems, councillors indicated that ABU members had not accepted any of their invitations to attend sensitization meetings in town because they were 'too busy farming'. Local agricultural extension staff (who work under the Ministry of Agriculture) reported that they also felt excluded from the ABU scheme because they had not been asked to participate in any of the initial sensitization induction meetings with farmers, or the seed delivery plan. Instead, 'master trainers' from Freetown were employed by the central government to work with local communities from the outset. This reportedly caused great feelings of resentment amongst extension staff, who added that because the master trainers were 'outsiders' and were not knowledgeable about local conditions, they had spread a considerable amount of misinformation.

Perhaps of greater concern, however, have been efforts at carrying out the seed procurement programme. In fact, in a number of cases, our field observations suggest that the seed programme has proved to be disastrous. For each district, the Ministry of Agriculture has earmarked sufficient funds to the councils so that seeds can be purchased for distribution to the ABU groups and other qualifying associations. However, rather than transferring the funds directly to the councils, in most cases, 'seed buyers' have been sub-contracted by the Ministry. The funds allocated to these 'middle-men' are supposed to cover the cost of transporting the seed to distribution sites, which is necessary since the seed has to be sourced from many different locations in each district. Reports suggest that because proper fiscal decentralization has not taken place and funds have not been directly under the control of the councils, there have been concerns about accountability, resulting in serious accusations of corruption. For example, interviews with councillors in Dodo Chiefdom, and Lower Bambara Chiefdom in Kenema District, revealed that there has been widespread mismanagement of funds. The budget allocated for seed purchase in Kenema District in 2005 was calculated to secure a target of 9600 bushels of rice seed, but only 5000 bushels were ultimately supplied. Consequently, instead of each ABU group receiving 240 bushels of seed as was originally planned, only 76 bushels were allotted to each group. Councillors did not know, and could not explain what had happened to the 'missing' funds which were supposed to be used for seed purchase. Concerns were also voiced for the seed procurement program in 
Kono District, with the main grievance being the very late arrival of seeds. In fact, the ABU group in Kayima did not receive its supply of seeds until August 1st 2005, long after the time when planting should have taken place. This being the case, many of the angry farmers announced that rather than saving the seed for next year's planting season, they were going to eat it instead.

At present, the structures of governance reform still appear to be in an embryonic stage, and it is perhaps too early to tell if decentralization, or the $\mathrm{ABU}$ experiment, will offer any real improvements for agriculture or rural livelihoods in Sierra Leone. While some critics have argued that the proponents of decentralization are expecting 'too much too quickly', the fact that the decentralization progress is so slow in gaining momentum may be telling in itself. As Jackson (2007) notes, governance reform has resulted in a series of political struggles between those who consider themselves to be the 'winners' and 'losers' of decentralization, and it is the outcome of these confrontations that will determine the future of local government. The ABU initiative is but one attempt to restructure local farming institutions, a step which is absolutely vital for enhancing rice production in the inland valley swamps and re-building national food security. Ultimately, however, it is the questions that concern power relationships and the effectiveness of rural governance that are the most pressing issues ahead. Paying attention to these critical factors remains paramount in ensuring that the positive benefits of decentralization stand a better chance of being achieved.

\section{Conclusion}

During the course of fieldwork for this paper, farmers in both Ethiopia and Sierra Leone demonstrated a wealth of environmental knowledge and displayed great skill in manipulating a range of environmental features in the management of their wetland plots. However, it was also apparent that differences in the capabilities, opportunities and constraints of individual actors played a significant role in defining their management abilities. One of the central points raised in this paper has been that it remains important to explore the role that power relationships assume at all scales, in formulating land-use decisions and determining access to resources within wetland environments. The fieldwork suggests that although the community-based institutions do have much in common with traditional, indigenous institutions cited in the much of the literature - i.e. in terms of social capital, reciprocal arrangements and common goals - they do not operate in isolation. Their evolution and effectiveness as NRM institutions have been shaped by their relationship with external local governance institutions - particularly those in Sierra Leone, but even those in Ethiopia which have their roots in traditional cultural institutions. Indeed, what the Ethiopian case highlights is that 'indigenous' roots do not guarantee a successful or sustainable community NRM institution. Similarly, in the Sierra Leonean case, although present-day management institutions are based on traditional arrangements, the challenges - especially to do with mobilizing labour - remain as great as ever. In short, in both cases, external institutions, particular government policies and requirements have been imposed upon communities, in some cases facilitating, and in others compromising, the effectiveness of local management arrangements for wetland resources. Moreover, within community institutions themselves, political and social relationships continue to evolve and influence management opportunities and abilities.

In both Ethiopia and Sierra Leone, the creation of democratic, accountable institutions at all scales, that increase equity and empower grassroots decision-making abilities will be essential in making wetland food production more effective and sustainable. However, although 'good governance' remains an essential pre-condition to sustainable development, both case studies demonstrate that the institutional arrangements of decentralization are embedded in a series of larger political and economic struggles. Hence, although in theory decentralization should complement and facilitate space for communitybased institutional arrangements that support sustainable wetland use, in practice, its politically motivated interventionist nature has eroded social capital and subsequently the functionality and effectiveness of wetland management arrangements. At the present time, therefore, the form of decentralization occurring in both Ethiopia and Sierra Leone appears to be largely incompatible with sustainable local institutional arrangements for sustainable wetland use. It is important to recognize, however, that these external-local institutional relationships are fairly recent phenomena, as is the intensification of wetland agriculture itself. As such, they may be entrenched in what Pretty and Ward (2001) term the reactive-dependence stage of local institutional development, in which the immaturity of the institution is characterized by a dependency on 'enabling' external institutions, and less resilience to shocks and pressures. Only time will tell whether the impacts of decentralization are such that they ultimately inhibit the adaptation and development of more mature, independent, resilient and sustainable institutions.

\section{References}

Abebe, Y., \& Geheb, K. (2003). Wetlands of Ethiopia. Gland: IUCN.

Acreman, M. C., \& Hollis, G. E. (1996). Water management and wetlands in sub-Saharan Africa. Gland: IUCN.

Adams, W. M. (1993). Indigenous use of wetlands and sustainable development in West Africa. The Geographical Journal, 159(2), $209-218$.

Adebajo, A. (2002). Sierra Leone: a feast for the sobels. In A. Adebajo (Ed.), Building peace in West Africa: Liberia, Sierra Leone and Guinea-Bissau. International Peace Academy Occasional Paper Series (pp. 79-109). London: Lynne Rienner Publishers.

Adger, W. N. (2000). Social and ecological resilience: are they related? Progress in Human Geography, 24, 347-364.

Agrawal, A. (2001). Common property institutions and sustainable governance of resources. World Development, 29, 1649-1672.

Berry, S. (1989). Social institutions and access to resources. Africa, 59, 41-55.

Berry, S. (2004). Reinventing the local? Privatization, decentralization and the politics of resource management: examples from Africa. African Study Monographs, 25, 79-101. 
Blunt, P., \& Warren, D. M. (1996). Indigenous organizations and development. London: ITDG Publishing.

Chambers, R. (1997). Whose reality counts? Putting the last first. London: ITDG Publishing.

Crook, R. (2003). Decentralisation and poverty reduction in Africa: the politics of local-central relations. Public Administration and Development, 23, 77-88.

Davies, S. Livelihood adaptation. Paper presented for workshop, 'Making livelihoods work - women, men and children in Rajasthan', 1997, Mimeo, Brighton: IDS.

Desalegn, C., Singh, M., Das Gupta, A., \& Seleshi, B. (2007). Indigenous systems of conflict resolution in Oromia, Ethiopia. In B. van Koppen, M. Giordano, \& J. Butterworth (Eds.), Community-based water law and water resources management reform in developing countries (pp. 146-159). Wallingford: CABI International.

Dixon, A. B. (2003). Indigenous management of wetlands: Experiences in Ethiopia. Aldershot: Ashgate.

Dixon, A. B. (2005). Wetland sustainability and the evolution of indigenous knowledge in Ethiopia. The Geographical Journal, 171, 306-323.

Dixon, A. B., \& Wood, A. P. (2003). Wetland cultivation and hydrological management in East Africa: matching community and hydrological needs through sustainable wetland use. Natural Resources Forum, 27(2), 117-129.

Dixon, A. B., \& Wood, A. P. (2007). Local institutions for wetland management in Ethiopia: sustainability and state intervention. In B. van Koppen, M. Giordano, \& J. Butterworth (Eds.), Community-based water law and water resources management reform in developing countries (pp. 130-145). Wallingford: CABI International.

Dugan, P. J. (1990). Wetland conservation: A review of current issues and action. Gland: IUCN.

Fabricius, C., Koch, E., Turner, S., \& Magome, H. (Eds.). (2004). Rights, resources and rural development: Community based natural resource management in Southern Africa. London: Earthscan.

Fanthorpe, R. (2006). On the limits of liberal peace: chiefs and democratic decentralization in post-war Sierra Leone. African Affairs, 105, 27-49.

Fine, B. (2001). Social capital versus social theory: Political economy and social science at the turn of the millennium. London: Routledge.

Gichuki, F. N. (1992). Utilisation and drainage of wetlands: an agricultural drainage perspective. In S. A. Crafter, S. G. Njuguna, \& G. W. Howard (Eds.), Wetlands of Kenya (pp. 147-154). Gland: IUCN.

Government of Sierra Leone. (2003). Sierra Leone vision 2025. Freetown: Government of Sierra Leone.

Government of Sierra Leone. (2004). Sierra Leone poverty reduction strategy paper (PRSP): Agricultural sector. Freetown: Government of Sierra Leone.

Grenier, L. (1998). Working with indigenous knowledge: A guide for researchers. Ottawa: IDRC.

Hamer, J. (2007). Decentralization as a solution to the problem of cultured diversity: an example from Ethiopia. Africa, 77, $207-225$.

Hanlon, J. (2005). Is the international community helping to recreate the preconditions for war in Sierra Leone? The Round Table, 94, 459-472.

Harriss, J., \& de Renzio, P. (1997). An introductory biographic essay. 'Missing link' or analytically missing? The concept of social capital. Journal of International Development, 9, 919-937.

Hollis, G. E. (1990). Environmental impacts of development on wetlands in arid and semi-arid lands. Hydrological Sciences Journal, 35 , 411-428.

Jackson, P. (2005). Chiefs, money and politicians: rebuilding local government in post-war Sierra Leone. Public Administration and Development, 25, 49-58.

Jackson, P. (2007). Reshuffling an old deck of cards? The politics of local government reform in Sierra Leone. African Affairs, 106, 95-111.

Kabbah, A. T. (2002). Inaugural address by his excellency Alhaji Dr. Ahmad Tejan Kabbah. Delivered on the occasion of the State Opening of the first session of the first parliament of the Third Republic, Parliament Building, Tower Hill, Freetown. http://www.sierra-leone.org/kabbah071202.html. Accessed 12.07.02.

Kangalawe, R. Y. M., \& Liwenga, E. T. (2005). Livelihoods in the wetlands of Kilombero Valley in Tanzania: opportunities and challenges to integrated water resource management. Physics and Chemistry of the Earth, 30, 968-975.

Larson, A., \& Ribot, J. (2004). Democratic decentralization through a natural resource lens: an introduction. The European Journal of Development Research, 16, $1-25$.

Leach, M., Mearns, R., \& Scoones, I. (1997). Environmental entitlements: A framework for understanding the institutional dynamics of environmental change. IDS Discussion Paper 359. Brighton: Institute of Development Studies.

Leach, M., Mearns, R., \& Scoones, I. (1999). Environmental entitlements: dynamics and institutions in community-based natural resource management. World Development, 27, 225-247.

McCann, J. (1995). People of the plow: An agricultural history of Ethiopia 1800-1990. Wisconsin: University of Wisconsin Press.

Mamdani, M. (1996). Citizen and subject: Contemporary Africa and the legacy of late colonialism. Princeton: Princeton University Press.

Manig, W. (1999). Have societies developed indigenous institutions enabling sustainable resource utilization? Journal of Sustainable Agriculture, 14, 35-52.

Mazzucato, V., \& Niemeijer, D. (2002). Population growth and environment in Africa: local informal institutions, the missing link. Economic Geography, 78, 171-193.

Mehta, L., Leach, M., Newell, P., Scoones, I., Sivaramakrishnan, K., \& Way, S. (1999). Exploring understandings of institutions and uncertainty: New directions in natural resource management. IDS Discussion Paper 372. Brighton: Institute of Development Studies.

Millennium Ecosystem Assessment (MEA). (2005). Ecosystems and human well-being: Wetlands and water synthesis. Washington, DC: World Resources Institute.

Narayan, D., \& Pritchett, L. (1999). Cents and sociability: household income and social capital in rural Tanzania. Economic Development and Cultural Change. 47, 871-897.

Nicholas, G. P. (1998). Wetlands and hunter-gatherers: a global perspective. Current Anthropology, 39, 720-731.

Noyes, F. (2003). Preventive diplomacy in Sierra Leone. In H. Solomon (Ed.), Towards sustainable peace: The theory and practice of preventive diplomacy in Africa (pp. 44-99). Pretoria: The Africa Institute of South Africa.

Ntsebeza, L. (2004). Democratic decentralization and traditional authority: dilemmas of land administration in rural South Africa. The European Journal of Development Research, 16, 71-89.

de Oliveira, J. A. P. (2002). Implementing environmental policies in developing countries through decentralization: the case of protected areas in Bahia, Brazil. World Development, 30(10), 1713-1736.

Pretty, J., \& Ward, H. (2001). Social capital and the environment. World Development, 29, 209-227.

Rasmussen, L. N., \& Meinzen-Dick, R. (1995). Local organisations for natural resource management: Lessons from theoretical and empirical literature. EPTD Discussion Paper No. 11. Washington: International Food Policy Research Institute.

Ribot, J. (2004). Waiting for democracy: The politics of choice in natural resource decentralization. Washington: World Resources Institute.

Richards, P. (1995). The versatility of the poor: indigenous wetland management systems in Sierra Leone. Geojournal, 35, $197-203$.

Richards, P. (1996). Fighting for the rainforest: War, youth and resources in Sierra Leone. Oxford: James Currey.

Richards, P., Bah, K., \& Vincent, J. (April 2004). Social capital and survival: Prospects for community-driven development in post-conflict Sierra Leone. Social Development Paper No. 12. Washington: The World Bank.

Roggeri, H. (1998). Tropical freshwater wetlands: A guide to current knowledge and sustainable management. Dordrecht: Kluwer Academic Publishers.

Schuyt, K. D. (2005). Economic consequences of wetland degradation for local populations in Africa. Ecological Economics, 53, 177-190.

Scoones, I. (1992). Wetlands in drylands: The agro-ecology of savannah systems in Africa. London: IIED Drylands Programme.

Shivakumar, J. (2003). The place of indigenous institutions in constitutional order. Constitutional Political Economy, 14, 3-21.

Silvius, M. J., Oneka, M., \& Verhagen, A. (2000). Wetlands: lifeline for people at the edge. Physics and Chemistry of the Earth (B), $25,645-652$.

Solomon, M. (2004). Socio-economic determinants of wetland cultivation in Kemise, Illubabor Zone, Southwestern Ethiopia. Eastern Africa Social Science Research Review, 20, 93-114.

Stuip, M. A. M., Baker, C. J., \& Oosterberg, W. (2002). The socio-economics of wetlands. Wageningen: Wetlands International.

Toulmin, C. (2000). Decentralization and land tenure. In C. Toulmin, \& J. Quan (Eds.), Evolving land rights, policy and tenure in Africa (pp. 229-245). London: IIED. 
UN. (2004). United Nations transitional appeal for relief and recovery. Freetown: UNDP.

UNDP. (2006). The agricultural business unit programme. Progress Report September 2004-December 2005. Freetown: UNDP.

Uphoff, N. (1992). Local institutions and participation for sustainable development. Gatekeeper Series No 31. London: IIED.

Watson, E. (2001). Inter-institutional alliances and conflicts in natural resource management. Marena Working Paper 4. Brighton: Institute of Development Studies.

Watson, E., Black, R., \& Harrison, E. (1999). Reconstruction of natural resource management institutions: A framework for research. Marena Research Project Working Paper No. 1. Brighton: Institute of Development Studies.

Wood, A. P. (1983). Rural development and national integration in Ethiopia. African Affairs, 82, 509-539.

Wood, A. P., Rushworth, G., \& Corr, J. Human impact on the valley systems of the South-West Ethiopian highlands: implications for development. Paper presented at the Institute of British Geographers/Royal Geographic Society Annual Conference, September 2005, London. 